Volume 5 Issue 2, September 2020: pp. 135-148 . Copyright @ LamLaj. Faculty of Law, Lambung Mangkurat University, Banjarmasin, South Kalimantan, Indonesia. ISSN: 2502-3136 | e-ISSN: 2502-3128. Open Access at: http://lamlaj.ulm.ac.id/web/

\title{
KONSTRUKSI HUKUM PENERAPAN SANKSI PADA ATURAN KEWAJIBAN PENGELOLAAN SAMPAH OLEH PRODUSEN DI INDONESIA
}

\author{
Yessy Cornesia Irianto ${ }^{1}$, Nadia Imanda ${ }^{2}$ \\ Magister Kenotariatan Fakultas Hukum Universitas Airlangga \\ Jl. Dharmawangsa Dalam Selatan Surabaya, 60286, Indonesia \\ yessycornesiai@gmail.com \\ Magister Kenotariatan Fakultas Hukum Universitas Airlangga \\ Jl. Dharmawangsa Dalam Selatan Surabaya 60286, Indonesia \\ Nadia.imanda96@gmail.com
}

Submitted : 20/05/2020 Reviewed:22/09/2020 Accepted: 26/09/2020

Abstract: In Indonesia's positive law there is a provision on producers' obligations to manage andrecycle the waste from their production. In this regulation, there is a legal vacuum because there are no sanctions if the producer does not carry out his obligations in managing waste production.This implies there is no basis for preventive and repressive supervision of the implementation of producer obligations in waste management in Indonesia. This paper aims to construct waste management rules by legitimizing the principles of Good Corporate Governance (GCG) to companies in Indonesia, especially in waste management. Then to answer the problems in this paper, normative legal research is used using the statute approach and conceptual approach. The results of this study indicate that the urgency of the rules for applying sanctions is as a basis for supervision for law enforcers to take action against producers who do not carry out their obligation to manage their waste.Supervision through sanctions is carried out so that there is law enforcement for producers who do not enforce their obligation to manage waste so that they can be deterred from violating the regulations again

Keywords: Law Construction; Prodecuer; Waste Management

Abstrak: Dalam hukum positif Indonesia terdapat ketentuan kewajiban produsen untuk mengelola dan mendaur ulang sampah dari produksinya. Dalam aturan 
tersebut terdapat kekosongan hukum karena tidak mengatur sanksi apabila produsen tidak menjalankan kewajibannya dalam mengelola sampah produksinya. Hal tersebut berimplikasi tidak ada landasan upaya pengawasan secara preventif dan represif terhadap pelaksanaan kewajiban produsen dalam pengelolaan sampah di Indonesia. Tulisan ini bertujuan untuk mengkonstruksi aturan pengelolaan sampah dengan melegitimasi prinsip Good Corporate Governance (GCG) kepada perusahaan-perusahaan di Indonesia terutama dalam pengelolaan sampah. Untuk menjawab permasalahan dalam tulisan ini, digunakan jenis penelitian hukum normatif dengan pendekatan peraturan perundang-undangan dan pendekatan konseptual. Hasil penelitian menunjukkan bahwa urgensi aturan penerapan sanksi adalah sebagai landasan pengawasan bagi penegak hukum untuk menindak produsen yang tidak menjalankan kewajiban mengelola sampahnya. Pengawasan melalui sanksi yang dilakukan ini agar ada penegakan hukum bagi produsen yang tidak menjalankan kewajiban pengelolaan sampah sehingga bisa jera untuk tidak melanggar peraturan kembali.

Kata Kunci: Konstruksi Hukum; Pengelolaan Sampah; Produsen.

\section{PENDAHULUAN}

Setiap orang berhak hidup sejahtera lahir dan batin, bertempat tinggal, dan mendapatkan lingkungan yang baik dan sehat serta berhak memperoleh pelayanan kesehatan. Kalimat tersebut merupakan amanat Pasal $28 \mathrm{H}$ ayat (1) UUD 1945. Karena itu adalah amanat UUD yang menjadi konstitusi bagi negara Indonesia, maka dari itu menjadi hak bagi warga negara dan pemerintah wajib mewujudkan. Salah satunya adalah perwujudan lingkungan yang baik dan sehat di masyarakat. Untuk mewujudkan tersebut maka negara melalui lembaga tingginya mengeluarkan upaya-upaya melalui aturan untuk mengatur lingkungan hidup dan yang paling spesifik tentang aturan tentang pengelolaan sampah.

Pada tahun 2008 Dewan Perwakilan Rakyat telah mengundangkan aturan khusus untuk mengatasi permasalahan pengelolaan sampah di Indonesia. Aturan tersebut adalah Undang-Undang Nomor 18 Tahun 2008 Tentang Pengelolaan Sampah (UU Pengelolaan Sampah). Diundangkannya UU tersebut ten- tu bertujuan memberikan kepastian hukum dalam pengelolaan sampah. Dalam rangka sebagai pedoman pengelolaan sampah untuk menciptakan lingkungan yang bersih dan sehat.

Secara global persoalan sampah telah menjadi momok internasional yang perlu diperdulikan. Saat ini tercatat 150 juta ton plastik di lautan dunia. Jumlah ini akan meningkat sebesar 250 juta lagi jika tren urbanisasi, produksi, dan konsumsi terus berlanjut. Sebuah laporan dari World Economic Forum dan Ellen MacArthur Foundation memperkirakan bahwa pada tahun 2050 akan ada "lebih banyak plastik ketimbang ikan (berdasarkan berat)," kecuali bila terdapat "jalur-jalur paska-guna yang efektif untuk plastik; pengurangan kebocoran plastik ke sistem-sistem alami secara drastis, khususnya lautan; dan penghentian penggunaan plastik berbasis fosil. ${ }^{1}$

\footnotetext{
1 World Economic Forum, Ellen Mac Arthur Foundation, and McKinsey \& Company, The new plastics economy: Rethinking the future of plastics, World Economic Forum (Cologny, 2016).
} 
Walapun telah diundangkannya UU Pengelolaan Sampah, permasalahan sampah di Indonesia masih belum bisa terselesaikan. Pada tahun 2010, Indonesia menghasilkan 3,22 juta ton sampah yang tak terkelola dengan baik, dan diperkirakan mengakibatkan kebocoran 0,48-1,29 juta ton metrik sampah plastik per tahun ke lautan. Hal itu juga diperkuat oleh data yang pernah dipublikasikan Kementerian Lingkungan Hidup dan Kehutanan (KLHK) menyebutkan jumlah rata-rata produksi sampah di Indonesia mencapai 175.000 ton per hari atau setara dengan 64 juta ton per tahun. Bila menggunakan asumsi berdasarkan data itu, sampah yang dihasilkan setiap orang per hari sebesar 0,7 kilogram (kg). Bahkan, berdasarkan studi yang dirilis oleh McKinsey and Co dan Ocean Conservancy, Indonesia disebut sebagai negara penghasil sampah plastik nomor dua di dunia setelah Tiongkok. ${ }^{2}$

Dalam hal meminimalisir penumpukan sampah pemerintah Indonesia seharusnya mencontoh pengelolaan sampah dari negara maju yang menggunakan Program-program pengurangan sampah. Contoh misalnya seperti Amerika Serikat telah terbukti efektif dalam pengelolaan sampah. Kemudian Korea Selatan juga memiliki program pengelolaan sampah yang baik. Pengelolaan sampah di Korea Selatan menggunakan prinsip Extended Producer Responsibiity (EPR) yang kemudian terbukti dapat terciptanya pegelolaan sampah secara efektif ${ }^{3}$. Berdasarkan EPR, ada

\footnotetext{
2 "Hospot Sampah Laut Indonesia" The World Bank, accessed September 10, 2019, http://documents. worldbank.org/curated/en/642751527664372193/ pdf/126686-INDONESIA-29-5-2018-14-345SynthesisFullReportAPRILIND.pdf

3 "Belajar Mengelola Sampah dari Korea" Situs Hijau Indonesia, accessed September 11, 2019, https:// www.hijauku.com/2011/09/07/belajar-mengelolasampah-dari-korea/
}

pemberian perluasan tanggung jawab kepada produsen terutama kewajiban melakukan pengelolaan sampah secara mandiri.

UU Pengelolaan Sampah sebenarnya memiliki ketentuan hukum untuk dapat melibatkan produsen terlibat dalam pengelolaan sampah. Hal tersebut diatur dalam Pasal 15 UU Pengelolaan Sampah yang menyebutkan. "Produsen wajib mengelola kemasan dan/ atau barang yang diproduksinya tidak dapat atau sulit terurai oleh proses alam”.

Produk yang dikonsumsi biasa meninggalkan kemasan. Kemasan itu adalah suatu sisa dari produk yang sudah dikonsumsi. Karena kemasan berasal dari sisa produk, maka berdasarkan UU Pengelolaan Sampah sisa kemasan tersebut merupakan sampah. Sehingga berdasarkan amanat UU produsen wajib mengelola kemasan terutama pada pengelolaan sisa kemasan produk dari aktivitas produksinya.

Penegasan spesifik kewajiban produsen salam mengelola sampah terdapat pada PP Nomor 81 Tahun 2012 Tentang Pengelolaan Sampah Rumah Tangga danSampah Sejenis Sampah Rumah Tangga sebagai aturan pelaksana Pasal 15 UU Pengelolaan Sampah, dalam Pasal 13 mengatur lebih spesifik tentang kewajiban pengelolaan sampah dengan mendaur ulang sisa kemasan produk.

Permasalahan sampah di Indonesia yang terjadi tidak hanya karena faktor teknis, namun juga ada permasalahan hukum dalam aturan tersebut. Bahwa permasalahan yang terdapat dalam UU Pengelolaan Sampah akibat ada kekosongan hukum, yaitu tidak mengatur penerapan sanksi terutama yang bisa diberlakukan kepada produsen apabila tidak menjalankan kewajiban dalam mengelola kemasan berdasarkan Pasal 15 UU Pengelolaan sampah. Hal tersebut berimplikasi tidak 
ada upaya pengawasan secara preventif dan represif terhadap pelaksanaan kewajiban produsen dalam pengelolaan sampah. Padahal kedudukan sanksi memiliki peran sebagai upaya pengawasan yang lebih tegas kepada para produsen. Apabila ada aturan sanksi bisa berperan untuk menindak produsen yang tidak menjalankan kewajibannya berdasarkan UU.

Atas dasar permasalahan diatas akan ditarik rumusan masalah yaitu "bagaimana konstruksi hukum penerapan sanksi pada aturan kewajiban pengelolaan sampah oleh produsen? Tulisan ini dilakukan sebagai salah satu sumbangsih pemikiran pembaharuan hukum pengaturan sampah di Indonesia. Urgensi sanksi adalah agar pemerintah dapat melakukan pengawasan dalam pelaksanaan aturan tentang sampah dan melegitimasi prinsip Good Corporate Governance (GCG) kepada perusahaan-perusahaan di Indonesia untuk perduli terhadap lingkungan terutama dalam pengelolaan sampah.

\section{METODE}

Jenis penelitian menggunakan metode penelitian hukum normatif, yaitu penelitian yang difokuskan untuk mengkaji penerapan kaidah-kaidah atau norma-norma dalam hukum positif4. Pendekatan penelitian menggunakan pendekatan peraturan perundang-undangan (statute approach) yaitu UU Nomor 18 Tahun 2008 Tentang Pengelolaan Sampah, juga menggunakan pendekatan penelitian konseptual (conceptual approach) yang telah dipilih dan menjadi acuan pembahasan.

Bahan hukum menggunakan bahan hukum primer dan bahan hukum sekunder. Bahan hukum primer terdri peraturan per-

\footnotetext{
${ }^{4}$ Ibrahim Johny, Teori dan Metodologi Penelitian Hukum Normatif, (Malang: Bayumedia, 2006), 74
}

udang-undangan seperti: Undang-undang Dasar Negara Republik Indonesia Pasal 28 (H), Undang-undang Nomor 18 Tahun 2008 Tentang Pengelolaan Sampah dan Peraturan Pemerintah Nomor 81 Tahun 2012 Tentang Pengelolahan Sampah Rumah Tangga dan Sampah Sejenis Sampah Rumah Tangga. Kemudian bahan hukum sekunder terdiri dari karya tulis hukum (Buku, Jurnal, Artikel). Teknik pengumpulan bahan hukum yang digunakan dalam penulisan ini adalah dengan studi kepustakaan. Studi kepustakaan dilakukan dengan cara membaca, menelaah, mencatat membuat ulasan bahan-bahan hukum yang ada kaitannya dengan aturan dan konsep pengelolaan sampah.

Cara untuk menarik kesimpulan dari fakta hukum yang ada dan untuk mencari jawaban dari isu hukum digunakan prosedur dalam melakukan penelitian hukum. Tujuan yang digunakan dalam penggunaan bahan hukum serta pendekatan agar: dapat mengidentifikasi fakta hukum dan mengeliminir hal-hal yang tidak relevan untuk menetapkan isu hukum yang hendak dipecahkan. Pengumpulan bahan-bahan hukum dan sekiranya dipandang mempunyai relevansi juga bahan-bahan nonhukum. Melakukan telaah atas isu hukum yang diajukan berdasarkan bahan-bahan yang telah dikumpulkan. Menarik kesimpulan dalam bentuk argumentasi yang menjawab isu hukum. Memberikan preskripsi berdasarkan argumentasi yang telah dibangun di dalam kesimpulan.

Pada penelitian hukum normatif, pengolahan bahan hukum dilakukan dengan cara men- ${ }^{5}$ sistematika terhadap bahan-bahan hukum tertulis. Sistematisasi berarti membuat klasifikasi terhadap bahan hukum tersebut

\footnotetext{
${ }^{5}$ Soekanto Soerjono and Mamudji Sri, .Pengantar Penelitian Hukum, (Jakarta: UI Press, 1981), 10.
} 
untuk memudahkan pekerjaan analisis dan konstruksi terutama memberikan konstruksi pada pembaharuan UU Pengelolaan Sampah di Indonesia.

\section{ANALISIS DAN PEMBAHASAN \\ Partisipasi Produsen Dalam Pengelolaan Sampah Sebagai Pelaksanaan Asas Good Corporate Governance (GCG)}

Good Corporate Governance (GCG) atau tata kelola perusahaan yang baik memiliki banyak definisi dari berbagai sudut pandang, semuanya memiliki tujuan yang sama hanya saja disesuaikan dengan negara atau tempat di mana GCG diterapkan. Definisi GCG sendiri menurut FCGI (Forum for Corporate Governance Indonesia), di mana GCG merupakan seperangkat peraturan yang mengatur hubungan antara semua pihak yang terlibat dengan perusahaan. Mulai dari pemangku kepentingan, pengurus, pihak kreditur, pemerintah, karyawan, serta para pemegang kepentingan internal dan eksternal lainnya yang berkaitan dengan hak dan kewajiban mereka. ${ }^{6}$ Tujuan dari penerapan GCG ini ialah agar perusahaan dapat mengembangkan pola manajemen yang bermutu, sehingga dapat disejajarkan atau dibandingkan dengan perusahaan lain di seluruh dunia. Salah satu sarana untuk mengembangkan pola manajemen yang berkelas dunia adalah dengan menggunakan corporate governance.

Untuk pengaturan GCG sendiri berbagai aturan main dan sistem yang mengatur keseimbangan dalam pengelolaan perusahaan perlu dituangkan dalam bentuk prinsip-prinsip yang harus dipatuhi untuk menuju tata kelola perusahaan yang baik. Beberapa prinsip

\footnotetext{
6 I Nyoman Tjager et al., Corporate Governance Tantangan dan Kesempatan Bagi Komunitas Bisnis Indonesia, (Jakarta:PT. Perenhallindo, 2003), 55.
}

dasar yang harus diperhatikan dalam Corporate Governance, yaitu:

1. Transparancy (Keterbukaan) Penyediaan informasi yang memadai, akurat, dan tepat waktu kepada stakeholders harus dilakukan oleh perusahaan agar dapat dikatakan transparan.

2. Accountability (Dapat Dipertanggungjawabkan). Akuntabilitas adalah kejelasan fungsi, struktur, sistem dan pertanggungjawaban organ perusahaan sehingga pengelolaan perusahaan terlaksana secara efektif.

3. Fairness (Kesetaraan). Secara sederhana kesetaraan didefinisikan sebagai perlakuan yang adil dan setara dalam memenuhi hakhak stakeholder.

4. Sustainability (Kelangsungan). Kelangsungan adalah bagaimana perusahaan dapat terus beroperasi dan menghasilkan keuntungan. Ketika perusahaan negara (corporation) exist dan menghasilkan keuntungan dalam jangka mereka juga harus menemukan cara untuk memuaskan pegawai dan komunitasnya agar tetap bisa bertahan dan berhasil. Mereka harus tanggap terhadap lingkungan, memperhatikan hukum, memperlakukan pekerja secara adil, dan menjadi karyawan yang baik. Dengan demikian, akan menghasilkan keuntungan yang lama bagi stakeholdernya. $^{7}$

Terkait dengan prinsip-prinsip untuk menuju tata kelola perusahaan yang baik, salah satu prinsip subtainability (kelangsungan) menjelaskan bahwa bukan hanya keuntungan yang dicari namun kepuasan pegawai dan komunitasnya harus dijaga salah satunya dengan cara tanggap terhadap lingkungan

\footnotetext{
7 Adrian Sutedi, Good Corporate Governance, (Jakarta: Sinar Grafika, 2011), 10.
} 
sekitar tujuannya agar teciptanya kelangsungan hidup bagi lingkungan sekitar itu sendiri.

Dari prinsip tersebut pemerintah Indonesia sendiri telah membuat aturan terkait kelangsungan sampah yaitu dengan lahirnya Undang-Undang Nomor 18 Tahun 2008 Tentang Pengelolaan Sampah. Jika dilihat dalam UU Pengelolaan Sampah Nomor 18 Tahun 2008 Pasal 15 menyatakan produsen wajib mengelola kemasan dan/atau barang yang diproduksinya yang tidak dapat atau sulit terurai oleh proses alam. Hal inilah yang menjadi dasar terkait dengan pengelolaan sampah yang melibatkaan produsen (pelaku usaha) untuk pengelolahan sampah dengan prinsip Good Corporate Governance untuk Sustainability (Kelangsungan) dimana perusahaan harus tanggap terhadap lingkungan terutama pada keperdulian sampah dari produknya yang dapat mengganggu kualitas lingkungan di masyarkat.

\section{Pengelolaan Sampah Berdasarkan Sistem Extended Producer Responsibility (EPR) Dalam UU Pengelolaan Sampah}

Ketika berbicara tentang pengelolaan sampah yang melibatkan produsen maka tidak lepas dengan konsep yang telah dilakukan oleh beberapa negara maju. Adapun konsep tersebut adalah Extended Producer Responsibility (EPR) yang artinya perluasan tanggung jawab produsen. EPR merupakan pendekatan kebijakan lingkungan, dimana pertanggungjawaban produsen atas produknya diperluas hingga barang tersebut tidak dipakai lagi oleh konsumen ${ }^{8}$.

Konsep Extended Producer Responsi-

\footnotetext{
8 Organization For Economic Co-Coperation and Development (OECD), .Extended Producer Responsibility : A Guidance Manual For Governments, (Paris : OECD Publhising 2001), 9
}

bility (EPR) pertama kali di kenalkan oleh Thomas Lindhqvist pada tahun 1990, dalam laporan yang ditujukan untuk Kementerian Lingkungan Hidup Swedia. Thomas Lindhqvist mengatakan bahwa Extended Producer Responsibility (EPR) sebagai Tanggung Jawab Produsen Diperpanjang yang merupakan strategi perlindungan lingkungan untuk mencapai tujuan lingkungan dari total dampak lingkungan yang berkurang dari suatu produk, dengan membuat produsen produk yang bertanggung jawab untuk seluruh siklus hidup produk dan terutama untuk pengambilan kembali, daur ulang dan pembuangan akhir produk ${ }^{9}$.

Dalam konsep Extended Producer Responsibility (EPR) ini, produsen harus menerima tanggung jawab untuk membuat produk yang ramah lingkungan sehingga dapat meminimalisir dampak lingkungan.termasuk dampak hulu yang melekat pada pemilihan bahan untuk produk, dampak dari produsen proses produksi itu sendiri, dan dampak hilir dari penggunaan dan pembuangan produk. ${ }^{10}$ Tanggung jawab ini meluas di seluruh siklus hidup manajemen produk, meliputi pengurangan limbah, pemulihan, daur ulang, dan penggunaan kembali ${ }^{11}$.

Pasal 15 UU Pengelolaan Sampah terkait kewajiban produsen untuk mengelola sampahnya merupakan suatu kebijakan yang memiliki unsur sistem UPR.Pelaksanaan ke-

\footnotetext{
9 B.S. Sahay et al., Green Business, (New Delhi, Allied Publishers PVT, 2006), 696..

${ }^{10}$ Kevin Wehr and Paul Robbins, Green Culture An A-to-Z Guide, (California: SAGE Publication, 2011), 255.

${ }^{11}$ The Organisation for Economic Co-operation and Development (OECD), Extended Producer Responsibility: Updated Guidance for Efficient Waste Management, (Paris: OECD Publishing, 2016), 103104.
} 
wajiban produsen terhadap pengelolaan sampah yang diatur dalam peraturan formal di Indonesia berdasarkan pendekatan EPR maka dilakukan mulai dari awal produksi sampai dengan akhir produksi.Dalam konteks EPR pada awal produksi produsen wajib membuat produk yang ramah lingkungan dengan tujuan meminimalisir dampak lingkungan.Kemudian pasca produksi produsen tetap memiliki tanggung jawab terhadap produknya yang telah didistribusi yaitu terkait sampah produk tersebut seperi pengembalian kembali, daur ulang dan pembuangan akhir produk.

Penerapan konsep EPR berdasarkan ketentuan Pasal 15 Undang-Undang Pengelolaan Sampah ini didelegasikan ke dalam Pasal 12-15 PP Nomor 81 Tahun 2012, yang berbunyi:

\section{Pasal 12}

Produsen wajib melakukan pembatasan timbulan sampah dengan:

a. menyusun rencana dan/atau program pembatasan timbulan sampah sebagai bagian dari usaha dan/atau kegiatannya; dan/atau menghasilkan produk dengan menggunakan kemasan yang mudah diurai oleh proses alam dan yang menimbulkan sampah sesedikit mungkin.

\section{Pasal 13}

(1) Produsen wajib melakukan pendauran ulang sampah dengan:

a. menyusun program pendauran ulang sampah sebagai bagian dari usaha dan/atau kegiatannya;

b. menggunakan bahan baku produksi yang dapat didaur ulang; dan/atau

c. menarik kembali sampah dari produk dan kemasan produk untuk didaur ulang.

(2) Dalam melakukan pendauran ulang sampah sebagaimana dimaksud pada ayat (1),
(3) Pihak lain, dalam melakukan pendauran ulang sebagaimana dimaksud pada ayat (2), wajib memiliki izin usaha dan/atau kegiatan

(4) Dalam hal pendauran ulang sampah untuk menghasilkan kemasan pangan, pelaksanaan pendauran ulang wajib mengikuti ketentuan peraturan perundangan- undangan di bidang pengawasan obat dan makanan.

\section{Pasal 14}

Produsen wajib melakukan pemanfaatan kembali sampah dengan:

a. menyusun rencana dan/atau program pemanfaatan kembali sampah sebagai bagian dari usaha dan/atau kegiatannya sesuai dengan kebijakan dan strategi pengelolaan sampah;

b. menggunakan bahan baku produksi yang dapat diguna ulang; dan/atau c. Menarik kembali sampah dari produk dan kemasan produk untuk diguna ulang.

\section{Pasal 15}

(1) Penggunaan bahan baku produksi dan kemasan yang dapat diurai oleh proses alam, yang menimbulkan sesedikit mungkin sampah, dan yang dapat didaur ulang dan/ atau diguna ulang sebagaimana dimaksud dalam Pasal 12 sampai dengan Pasal 14 dilakukan secara bertahap persepuluh tahun melalui peta jalan.

(2) Pentahapan sebagaimana dimaksud pada ayat (1) diatur oleh menteri yang menyelenggarakan urusan pemerintahan di bidang perlindungan dan pengelolaan lingkungan hidup.

(3) Dalam menetapkan peta jalan sebagaimana dimaksud pada ayat (1) menteri yang menyelenggarakan urusan pemerintahan di bidang perlindungan dan pengelolaan lingkungan hidup berkoordinasi dengan 
menteri yang menyelenggarakan urusan pemerintahan di bidang perindustrian dan melakukan konsultasi publik dengan produsen.

(4) Ketentuan lebih lanjut mengenai tata cara pengurangan sampah diatur dengan peraturan menteri yang menyelenggarakan urusan pemerintahan di bidang perlindungan dan pengelolaan lingkungan hidup setelah berkoordinasi dengan menteri yang menyelenggarakan urusan pemerintahan di bidang perindustrian dan melakukan konsultasi publik dengan produsen.

\section{Implikasi Kekosongan Hukum Tidak Ada Sanksi Pada Aturan Kewajiban Produsen Dalam Mengelola Sisa Kemasan Produk (Sampah)}

Dalam UU Pengelolaan Sampah tidak terdapat aturan sanksi bagi produsen yang tidak menjalankan Pasal 15 dapat berakibat masalah dalam pelaksanannya. Salah satunya dalam aspek implementasi. Implementasi berdampak pada efektivitas berjalannya UU. Ketika berbicara konteks efektivitas banyak sekali aspek yang dapat dilihat. Salah satunya melalui political will penyelenggara negara terkait komitmen dalam pengelolaan sampah di Indonesia. Pentingnya komitmen negara dalam mengatur pengelolaan sampah melalui aturan harus melihat aspek-aspek yang wajib dipenuhi. Terutama aspek sanksi sebagai penindak pelanggar aturan. Tanpa ada sanksi dalam UU, akan menghambat terwujudnya komitmen yang sudah tertuang akibat sulit untuk menindak oknum pelanggar aturan.

Ketika tidak ada sanksi dalam suatu aturan, maka berimplikasi tidak ada pengawasan yang dapat dilakukan oleh Pemerintah melalui penegakan hukum (law enforcement).
Produksi sampah di Indonesia tidak lepas dari peran para produsen. Penyebaran sampah yang saat ini sulit dikendalikan tentu bisa berkaitan dengan oknum produsen yang tidak bertanggungjawab terhadap kewajibannya. Berdasarkan penelitian terbaru mengungkapkan Indonesia menduduki peringkat kedua di dunia sebagai penghasil sampah plastik yang bermuara ke lautan, yakni sebanyak 187,2 juta ton ${ }^{12}$. Selanjutnya fakta bahwa Indonesia merupakan penghasil sampah plastik terbesar kedua di dunia setelah China. Berdasarkan data tahun 2015, Indonesia memiliki timbunan sampah plastik mencapai 175.000 ton perhari ${ }^{13}$.Tentu ketika berbicara tentang sampah tidak lepas dari peran produsen yang aktif memproduksi berkemesan untuk didistribusi ke masyarakat. Maka dari itu perlu ada sebuah upaya pelibatan produsen terhadap tanggung jawab akan sampahnya dalam rangka melaksanakan perusahaan yang berdasarkan asas GCG dalam aspek keperdulian lingkungan.

Pelibatan produsen dalam pengelolaan sampah menjadi di Indonesia melalui aturan bersifat dwigenrecht (memaksa). Hal ini dilihat dalam pasal 15 UU Pengelolaan Sampah bahwa produsen wajib mengelola kemasannya. Yaitu wajib mengelola kemasan terutama sisa kemasan sisa produk yang menjadi sampah. Ketentuan kewajiban pengelolaan sampah kemasan bagi produsen diperjelas dalam Pasal 13 PP Nomor 81 Tahun 2012. Bahwa produsen wajib mendaur ulang sampah dari produk dan kemasan produk untuk didaur ulang.

Kata "wajib" dalam Pasal 15 UU Penge-

\footnotetext{
${ }^{12}$ Jenna R. Jambeck et al., "Plastic Waste Inputs from Land into the Ocean," Science 347, no. 6223, (2015):769, https://science.sciencemag.org/ CONTENT/347/6223/768.abstract..

${ }^{13}$ PT Sukses Sejahtera Energi, Transformasi Paradigma Penanganan Sampah, (Karanganyar: PT SSE, TT), 1
} 
lolaan Sampah memberikan arti bahwa aturan tersebut harus dilakukan dan tidak boleh dilanggar. Dari sifat itu produsen tidak boleh mengingkari atau melanggar. Namun yang menjadi masalah aturan kewajiban produsen di Pasal 15 UU Pengelolaan Sampah tidak dibarengi oleh sanksi apabila produsen tidak menjalankan aturan yang bersifat memaksa ini. Sehingga aturan ini tidak ada pengawasan melalui tindakan tegas kepada para produsen yang melanggar kewajibannya. Sehingga implikasi kekosongan hukum tidak ada sanksi dalam aturan kewajiban pengelolaan sampah adalah produsen yang melanggar ketentuan tersebut tidak dapat tindak. Maka ini menjadi celah bagi para produsen untuk bisa memilih tidak melakukan pengelolaan sampah karena tidak ada ancaman sanksi baik sanksi administratif, perdata maupun pidana apabila tidak patuh terhadap kewajiban yang diberikan dari amanat UU.

\section{Urgensi aturan sanksi sebagai Pengawasan Kewajiban Produsen terhadap Pengelo- laan Sisa Kemasan Produk (Sampah)}

Dalam pelaksanaan aturan perlu sebuah pengawasan agar bisa memonitoring kepatuhan keberlakuan aturan tersebut. Pengawasan merupakan suatu tindakan yang pada dasarnya diarahkan sepenuhnya untuk menghindari adanya kemungkinan penyelewengan atau penyimpangan atas tujuan yang akan dicapai. Melalui pengawasan diharapkan dapat membantu melaksanakan kebijakan yang telah ditetapkan untuk mencapai tujuan yang telah direncanakan secara efektif dan efisien.

Saiful Anwar menyebutkan pengertian pengawasan. Menurutnya pengawasan atau kontrol terhadap tindakan aparatur pemerintah diperlukan agar pelaksanaan tugas yang telah ditetapkan dapat mencapai tujuan dan terhindar dari penyimpangan-penyimpangan. ${ }^{14}$ Menurut M. Manullang bahwa, pengawasan adalah suatu proses untuk menetapkan suatu pekerjaan apa yang sudah dilaksanakan, menilainya dan mengoreksi bila perlu dengan maksud supaya pelaksanaan pekerjaan sesuai dengan rencana semula. ${ }^{15}$ Fungsi pengawasan dilaksanakan, agar memperoleh umpan balik (feed back) untuk melaksanakan perbaikan bila terdapat kekeliruan atau penyimpangan sebelum menjadi lebih buruk dan sulit diperbaiki. Pengawasan dimaksud memiliki fungsi untuk mengendalikan atau mengontrol sekaligus mengevaluasi segala bentuk kebijakankebijakan yang telah ditetapkan.

Dalam UU Pengelolaan Sampah telah mengatur mengenai kewajiban produsen dalam mengelola sampah dari produknya. Pasal 15 UU Pengelolaan Sampah menyatakan produsen wajib mengelola kemasan dan/atau barang yang diproduksinya yang tidak dapat atau sulit terurai oleh proses alam. Akan tetapi aturan tersebut tidak dibarengi dengan pengaturan sanksi yang diberikan apabila produsen tidak menjalankan kewajibannya tersebut. Frasa wajib dalam hal ini dinilai memiliki keharusan yang tidak dapat diindahkan karena sifatnya memaksa bukan hanya sekedar anjuran, atau himbauan semata. Hal inilah menimbulkan suatu kekosongan aturan terkait sanksi karena seharusnya dalam pengaturan mengenai pengelolaan sampah pada Pasal 15 memberikan suatu pemberian sanksi baik administratif, pidana, maupun perdata. Tujuannya agar apabila produsen lalai atau tidak menjalakan kewajibannya dapat

\footnotetext{
${ }^{14}$ Saiful Anwar, Sendi-Sendi Hukum Administrasi Negara, (Yogyakarya: Glora Madani Press, 2004), 127.

${ }^{15}$ M.Manullang, Dasar-Dasar Manajemen, (Jakarta : Ghalia Indonesia, 1995), 18..
} 
dikenakan sanksi jika melanggarnya.

Penulis beranggapan apabila berbicara mengenai sanksi merupakan suatu bentuk pengawasan dari pengeloaan sampah di indonesia itu sendiri yaitu dengan pengawasan preventif dan represif. Dalam aspek pengawasan preventif pengelolahan sampah ialah pengawasan yang bersifat mencegah. Mencegah artinya menjaga jangan sampai suatu kegiatan itu sampai terjerumus pada kesalahan. Pengawasan preventif adalah pengawasan yang bersifat mencegah agar perusahaan penghasil sampah dapat ikut berpartisipasi dalam pengelolaan sampah di Indonesia. Bukti nyata dari pengawasan preventif oleh pemerintah itu sendiri ialah dibentuknya Undang-Undang Nomor 18 Tahun 2008 tentang Pengelolaan Sampah Jo. Peraturan Pemerintah Nomor 81 Tahun 2012 Tentang Pengelolaan Sampah Rumah Tangga dan Sampah Sejenis Sampah Rumah Tangga.

Pengawasan preventif pada pengeloaan sampah merupakan konsekuensi dan tanggung jawab pemerintah dalam menjalankan kekuasaan pemerintahan yang memegang "monopoli' kekuasaan pemerintahan, sehingga pemerintah menentukan cara-cara tertentu misalnya dalam bentuk pengawasan preventif terkait pengelolaan sampah dengan membuat aturan mengenai sampah itu sendiri. Tujuannya tidak lain agar mencegah produsen dan pengahasil sampah betanggung jawab atas sampah yang dihasilkannya. Sedangkan pengawasan represif adalah bentuk pengawasan yang dilakukan setelah suatu keputusan mempunyai akibat hukum (rechtsgevolgen) baik dalam bidang aturan maupun dalam tugas pembatuan.Pengawasan represif dilakukan dalam bentuk pembatalan maupun penangguhan (sciorsing) terhadap produk-produk hukum yang dinilai bertentangan dengan ke- pentingan umum dan/ atau perundang-undangan yang lebih tinggi. Bentuk pengawasan represif ini dapat dilakukan setelah mempunyai akibat hukum, namun dalam aturan UU Pengelolaan Sampah tidak memuat sanksi administasi pidana maupun perdata terkait produsen yang tidak menjalankan kewajiban untuk mengelola sampah, hal inilah yang menyebabkan tidak adanya akibat hukum apabila produsen tidak mengelola sampah sesuai amanat dari undang-undang ini, walaupun akibat langsung dari pencemaran sampah di lingkungan nyata adanya namun dalam undang-undang ini tidak menjelaskan sanksi yang mengatur apabila produsen tidak melaksanakan kewajibannya untuk mengelola sampah itu sendiri.

Seperti tujuan dari pemberian sanksi tersebut Secara umum, sanksi dalam peraturan peraturan perundang-undangan, termasuk juga sanksi administratif, biasanya dikaitkan dengan atau sebagai konsekuensi dari suatu norma yang dirumuskan dalam bentuk larangan, perintah (keharusan), atau wajib (kewajiban). Suatu norma yang berisi larangan, perintah (keharusan), atau wajib (kewajiban) pada umumnya akan mengalami kesulitan dalam penegakannya apabila tidak disertai dengan sanksi. Ada beberapa tujuan pencantuman dan penerapan ketentuan sanksi dalam peraturan perundang-undangan, termasuk sanksi administratif. ${ }^{16}$

1. Pertama, sebagai upaya penegakan ketentuan peraturan perundang-undangan. Seperti diuraikan sebelumnya bahwa suatu norma yang mengandung laran-

\footnotetext{
${ }^{16}$ Wicipto Setiadi, "Sanksi Aministratif SebagaiSalah Satu Instrumen Penegakan Hukum Dalam Peraturan Perundang-undangan" Jurnal Legislasi Indonesia 6, no. 4 (2009): 606, http://e-jurnal.peraturan.go.id/ index.php/jli/article/view/336
} 
gan, perintah (keharusan), atau keharusan pada umumnya akan mengalami kesulitan dalam penegakannya apabila tidak disertai dangan sanksi. Pemberian sanksi akan memudahkan penegakan norma tersebut dan pada gilirannya kita akan melihat kedayagunaan/kehasilgunaan peraturan perundang-undangan tersebut. Selain itu, pencantuman sanksi juga merupakan upaya agar seseorang menaati ketentuan peraturan perundang-undangan. Urgensi perlunya dibentuk sanksi dalam aturan Kewajiban Produsen untuk mengelola sampah produknya sebagai penegakan hukum pelaksanaan pengelolaan sampah di Indonesia. Apabila ada sanksi, para produsen agar patuh untuk mentaati peraturan.

2. Kedua, memberikan hukuman bagi siapapun yang melakukan pelanggaran atas suatu norma peraturan perundang-undangan. Orang yang melakukan pelanggaran atas suatu norma memang sudah sepantasnya diberikan hukuman sesuai dengan berat/ ringannya pelanggaran tersebut. Hukuman tersebut menjadi sepadan/tepat apabila orang tersebut memang secara sengaja melakukan pelanggaran atas suatu norma. Orang yang melakukan pelanggaran secara sengaja dapat diasumsikan bahwa orang tersebut memang mempunyai niat/itikad tidak baik, sehingga orang tersebut pantas untuk mendapat hukuman/ganjaran yang setimpal. Urgensi pentingnya penerapan sanksi dalam aturan kewajiban produsen untuk mengelola sampahnya adalah sebagai penindak secara hukum. Yaitu apabila ada produsen yang tidak melaksanakan kewajiban tersebut, produsen akan dikenai hukuman karena telah melanggar aturan kewajiban pengelolaan sampah.

3. Ketiga, membuat jera seseorang untuk melakukan kembali pelanggaran hukum. Dengan dijatuhkannya sanksi diharapkan orang tidak akan melakukan kembali pelanggaran. Dalam hukum pidana hal ini dikenal dengan teori penjeraan. Keempat, mencegah pihak lain untuk melakukan pelanggaran hukum. Dengan adanya ancaman berupa sanksi diharapkan orang tidak akan melakukan pelanggaran hukum. Hal ini merupakan rambu-rambu atau peringatan agar seseorang tidak melakukan sesuatu yang dilarang. Ini menjadi penting bahwa penerapan sanksi pada aturan kewajiban produsen mengelola sampah. penerapan sanksi kepada produsen yang tidak mematuhi kewajibannya tersebut agar produsen jera dan bisa kembali patuh untuk melaksanakan kewajibannya.

\section{Konstuksi Hukum Penerapan Sanksi Dalam Pengelolaan Sisa Kemasan Produk (Sampah)}

Berbagai peraturan perundang-undangan yang dikeluarkan pemerintah harus dapat dijalankan dan ditegakkan apabila ada pelanggaran. Negara dalam hal ini pemerintah bertanggungjawab untuk menjaga aturan-aturan dalam perundang-undangan itu dijalankan. Dalam menegakkan aturan-aturan tersebut digunakan sanksi hukum. Keberadaan sanksi hukum diperlukan karena dengan ancaman hukuman diharapkan dapat dicapai paksaan rohani dan pengaruh mendidik terhadap yang berkepentingan.

Penegakan hukum administrasi negara oleh hukum pidana adalah mengenai sanksinya. Pentingnya sanksi pidana di dalam penegakan hukum administrasi negara oleh hukum pidana dapat dilihat dari pendapat Logeman yang dikutip Soehardjo Sastrosoehardjo bahwa hukum administrasi negara itu 
memberikan kaidah-kaidah yang membimbing turut serta pemerintah dalam pergaulan sosial ekonomi yaitu kaidah-kaidah yang oleh pemerintah sendiri diberi sanksi dalam hal pelanggaran. ${ }^{17}$

Dalam perkembangannya terjadi perubahan terhadap fungsi hukum pidana mengingat adanya pembangunan disegala bidang kehidupan dalam rangka mensejahterakan masyarakat, hukum pidana digunakan sebagai sarana oleh pemerintah untuk meningkatkan rasa tanggungjawab negara/pemerintah dalam rangka mengelola kehidupan masyarakat modern yang semakin kompleks. Sanksi pidana antara lain digunakan secara maksimal untuk mendukung norma hukum administrasi dalam pelbagai hal. Inilah yang dinamakan administrative penal law (verwaltungs strafrecht) yang termasuk dalam kerangka public welfare offenses(ordnungswidrigkeite n). ${ }^{18}$

Ruang lingkup dalam konstruksi hukum dalam pengelolaan sampah setiadknya harus mencakup tiga ketentuan yaitu kebijakan kriminalisasi, sistem pertanggungjawaban pidana dan sistem sanksi beserta aturan pemidanaan itu sendiri.

Dalam kebijakan kriminalisasi perbuatan yang sepatutnya dapat dipidana atau dikriminalisasikan pada umumnya adalah perbuatan yang dipandang merugikan atau membahayakan suatu kepentingan hukum. Dalam bidang

${ }^{17}$ T.H. Ranidajita, Eksistensi Sanksi Pidana Dalam Hukum Administrasi Negara Khususnya Hukum Pajak di Indonesia, Dalam : Masalah-Masalah Hukum (Semarang : FH-UNDIP No. 4 Tahun 1994), 21.

${ }^{18}$ Muladi, Proyeksi Hukum Pidana Materiil Indonesia di Masa Datang, (Naskah Pidato Pengukuhan, Semarang: Diucapkan pada Peresmian Penerimaan Jabatan Guru Besar Dalam Ilmu Hukum pada Fakultas Hukum Universitas Diponegoro, 1990), 148. pengelolaan sampah, maka perbuatan yang sepatutnya dilarang dan dapat dipidana adalah perbuatan-perbuatan beserta akibat-akibatnya yang dapat menyerang, mengancam, merugikan masyarakat maupun lingkungan

Dalam sistem pertanggungjawaban pidana ada beberapa yaitu subjek tindak pidana atau siapa yang melakukan tindak pidana dan siapa yang dapat dipertanggungjawabkan. Namun dalam perkembangannya, badan hukum (rechtspersoon) mulai diakui sebagai subjek tindak pidana. Berbagai peraturan perundangundangan mulai banyak merumuskan badan hukum sebagai subjek tindak pidana. Akan tetapi apabila "korporasi" sebagai subjek tindak pidana, maka masalahnya akan lebih rumit. Hal ini karena korporasi bisa menjadi pembuat tindak pidana tetapi belum tentu dapat dipertanggungjawabkan. Hal ini tergantung dari kebijakan formulasi dari pembuat undang-undang. Pencantuman badan hukum atau korporasi sebagai subjek tindak pidana sangat penting artinya karena membawa konsekuensi yuridis yaitu korporasi atau badan hukum dapat atau tidak dipertanggungjawabkan secara hukum pidana.

Dan yang terakhir jenis sanksi dan aturan pemidanaannya dapat berupa pidana dan juga pencabutan izin atau denda dua kali lipat dan pencabutan ijin. Dengan demikian pelanggaran-pelanggaran dibidang hukum administrasi yang penegakan hukumnya dengan hukum pidana masuk dalam ruang lingkup hukum pidana administrasi. Hukum pidana administrasi ini oleh Barda Nawawi Arief disebut dengan hukum pidana dibidang pelanggaran-pelanggaran hukum administrasi. Dari penjelasan diatas diharapkan agar pemerintah dalam hal ini DPR dapat membuat aturan atau memperbaharui aturan mengenai pengelolaahan sampah yang memuat setidak-tidaknya 
hal yang penulis kemukakan diatas terutama mengenai sanksi, tujuannya tidak lain agar pelaksanaan pengelolaan tentang sampah dapat berjalan sebagai mana mestinya.

\section{PENUTUP}

Dalam Pasal 15 UU Pengelolaan Sampah Jo. Pasal 13 PP Nomor 81 Tahun 2012 telah diatur tentang kewajiban produsen untuk mengelola sampah kemasan dari sisa produknya. Namun saat ini dalam UU Pengelolaan Sampah terdapat kekosongan hukum. Yaitu tidak ada sanksi yang bisa diterapkan jika produsen tidak melakukan kewajibanya untuk melakukan pengelolaan sampah kemasan produknya berdasarkan amanat hukum positif. Hal tersebut berimplikasi pada tidak ada ruang pengawasan oleh penegak kepada produsen yang tidak melakukan kewajiban pengelolaan sampah baik secara preventif maupun represif.Sehingga perlu ada konstruksi hukum penerapan sanksi yang diberlakukan di UU Pengelolaan Sampah terutama pada ketentuan kewajiban produsen dalam mengelola sampahnya. Hal tersebut agar dikemudian hari produsen yang tidak menjalankan kewajiban dalam pengelolaan sampah akan diberi sanksi agar kedepannya produsen bisa patuh kepada aturan dalam rangka pelaksanaan tata perusahaan yang baik berdasarkan asas Good Corporate Governance (GCG) di bidang keperdulian terhadap lingkungan.

\section{BIBLIOGRAFI}

\section{Buku}

Adrian Sutedi. Good Corporate Governance. Jakarta: Sinar Grafik, 2011.

B.S. Sahay, Roger R. Stough, Amrik Sohal, and Sonu Goyal. Green Business. New Delhi: Allied Publishers PVT, 2006.

I Nyoman Tjager, F.Antonius Alijoyo, Humphrey R. Djemat, and Bambang Soem- bodo. Corporate Governance Tantangan dan Kesempatan Bagi Komunitas Bisnis Indonesia. Jakarta:PT. Perenhallindo, 2003.

Ibrahim Johny. Teori dan Metodologi Penelitian Hukum Normatif. Malang: Bayumedia, 2006

Kevin Wehr and Paul Robbins. Green Culture An A-to-Z Guide. California: SAGE Publication, 2011.

M. Manullang. Dasar-Dasar Manajemen. Jakarta :Ghalia Indonesia, 1995.

Muladi. Proyeksi Hukum Pidana Materiil Indonesia di Masa Datang. Naskah Pidato Pengukuhan, Semarang: Diucapkan pada Peresmian Penerimaan Jabatan Guru Besar Dalam Ilmu Hukum pada Fakultas Hukum Universitas Diponegoro, 1990.

Organization For Economic Co-Coperation and Development (OECD). Extended Producer Responsibility : A Guidance Manual For Governments. Paris : OECD Publhising, 2001.

Saiful Anwar. Sendi-Sendi Hukum Administrasi Negara. Yogyakarya: Glora Madani Press, 2004.

Soekanto Soerjono, and Mamudji Sri. Pengantar Penelitian Hukum. Jakarta: UI Press, 1981.

The Organisation for Economic Co-operation and Development (OECD). Extended Producer Responsibility: Updated Guidance for Efficient Waste Management. Paris: OECD Publishing, 2016.

T.H. Ranidajita. Eksistensi Sanksi Pidana Dalam Hukum Administrasi Negara Khususnya Hukum Pajak di Indonesia. Dalam : Masalah-Masalah Hukum, Semarang : FH-UNDIP No. 4 Tahun 1994.

World Economic Forum, Ellen Mac Arthur Foundation, and McKinsey \& Company, 
The New Plastics Economy : Rethinking the Future of Plastics, World Economic Forum (Cologny, 2016)

\section{Jurnal}

Jambeck, Jenna R. , Roland Geyer, Chris Wilcox, Theodore R. Siegler, Miriam Perryman, Anthony Andrady, Ramani Narayan, and Kara Lavender Law. "Plastic Waste Inputs from Land into the Ocean." Science 347, no 6223 (2015):https://science.sciencemag.org/CONTENT/347/6223/768. abstract.

Setiadi, Wicipto. "Sanksi Aministratif Sebagai Salah Satu Instrumen Penegakan Hukum Dalam Peraturan Perundangundangan." Jurnal Legislasi Indonesia 6, No 4 (2009): http://e-jurnal.peraturan. go.id/index.php/jli/article/view/336

\section{Internet}

"Hospot Sampah Laut Indonesia." The World Bank. Last modified 2018. Accessed September 10, 2019. http:// documents.worldbank.org/curated/ en/642751527664372193/pdf/126686INDONESIA-29-5-2018-14-34-5SynthesisFullReportAPRILIND.pdf.

"Belajar Mengelola Sampah dari Korea." Situs Hijau Indonesia. Last modified 2011. Accessed September 11, 2019. https:// www.hijauku.com/2011/09/07/belajarmengelola-sampah-dari-korea/ 